\title{
International Price Differences in Ski Lift Tickets
}

\author{
MARTIN FALK
}

JEL-Classification: D40, F3, L83, L11.

Keywords: international price differences, ski areas, quality characteristics, quantile regressions.

\section{Introduction}

Lift ticket prices differ considerably across Alpine countries when expressed in a common currency. For example, based on a representative data set from the winter season 2010/2011, the average price of a one-day lift ticket is $€ 37$ in Austria, €34.50 in France, and €39.20 in Switzerland. Similarly, the six-day ski pass costs about $€ 177$ in Austria, €175 in France and $€ 188$ in Switzerland on average. One obvious factor of the price differences is the difference in VAT rates across countries. Countries with a higher value-added tax (VAT) rate experience higher prices. ${ }^{1}$ However, when prices are adjusted for differences in value-added tax across countries and then expressed in a common currency, the international price differences in one-day lift tickets remain quite large, ranging from $€ 33.30$ in Austria to $€ 32.60$ in France and $€ 36.10$ in Switzerland. Overall, French one-day lift tickets (net of VAT) are 10 per cent lower on average than those in Switzerland, and 13 per cent lower when the medians are compared. When lift ticket prices are measured as six-day ski passes (net of VAT) the price differential between the two countries is less much pronounced. However, average prices are difficult to compare because there are large difference in the characteristics of the ski resorts across countries.

a Austrian Institute of Economic Research (WIFO), Arsenal Objekt 20, A-1030 Vienna, Austria, E-mail: Martin.Falk@wifo.ac.at. I would like to thank two anonymous referees for valuable comments on an earlier draft. I would also like to thank Massimo Filippini, Rico Maggi, Wilfried Puhwein, and Laurent Vanat for their helpful comments and suggestions. I would also like to thank the participants of the EARIE 2007 conference in Valencia, the German Economic Association 2007 in Munich, and the 2008 Meeting of the Swiss Society of Economics and Statistics in Lausanne for their helpful comments.

1 The VAT rates for lift tickets are 10 per cent in Austria, 5.5 per cent in France, and 8 per cent in Switzerland. 
Prices are one of the most important factors in decisions regarding destinations and tourism demand (Forsyth and Dwyer, 2009; Lim, 2006). Knowledge of the price differences across countries and their determinants is not only useful for tourists, but may also provide some indication of the relative price competitiveness of destinations. Prices are also important for policy makers because they are a useful indicator of market integration.

In this paper, we look at the cross-sectional dimension of price differences in lift tickets across countries. In particular, we analyze the extent and determinants of international price differences in ski lift tickets in three Alpine countries - Austria, France, and Switzerland - based on a representative data set consisting of large and medium-sized ski areas. We estimate a price equation with one-day lift tickets and six-day lift passes as the dependent variables. Since there are large differences in the characteristics of ski areas across countries (e.g. size, altitude and quality of ski lifts, snowmaking capacity, proximity to nearest regional centres), we control for these differences when comparing lift ticket prices across countries. Another aim of the paper is to provide new insights on international price differences using quantile regressions at the $25^{\text {th }}$ and $75^{\text {th }}$ conditional percentiles. This allows us to investigate whether price differences across countries are different for the ski areas with (conditional) low and high ski lift ticket prices. To our knowledge, this is the first study on international price differences in lift tickets.

This paper also contributes to the literature on hedonic price analysis. The hedonic price model introduced by Rosen (1974) allows to investigate which characteristics are valued by consumers and to what extent. Numerous empirical applications can be found in applied business research and economics for goods, real estate and land prices. Relatively little attention has been paid thus far to the price-quality relationship, as it concerns ski lift companies. While there are already some studies for Austria and Switzerland (e.g. BERwert, Bignasca and Filippini, 1996; Falk 2008; Borsky and Raschky, 2009) a comprehensive analysis based on comparable data for two or more countries is not available so far.

Furthermore, this paper contributes to the increasing literature on international comparisons of price levels based on micro-data for a bundle of products and services (Broda and Weinstein, 2008; Crucini, Telmer and Zachariadis, 2005; Li, Gopinath, Gourinchas and Hsieh, 2010; Parsley and Wei, 2001). Other micro-level studies focus on specific products, such as televisions (IMBS, Mumtaz, Ravn and Rey, 2010) and books (Cabolis, Clerides, Ioannou and SEnft, 2007). Most of these studies have investigated the cross-sectional distribution of deviations in the law of one price rather than its changes over time. 
The main reason for the use of cross-sectional data is that the time-invariant component of variations of the law of one price's deviations is much higher than the in-country (i.e. time series) variation (Li, Gopinath, Gourinchas and Hsien, 2010). Another argument for studying the cross-sectional price differences is that economic theory gives much more guidance on deviations in the law of one price at the cross-sectional level than over time (i.e. in-country deviation). The basic finding of this literature is that the deviation in the law of one price is much smaller when prices at the micro-level are used instead of price indices at the aggregate level. Therefore, price-level data at the micro-level should be preferred. For instance, using 1,800 goods and services, CRUCINI, Telmer and Zachariadis (2005) find that deviations in the law of one price at different cross-sections are nearly non-existent when VAT and income differences are accounted for.

Another basic result of the literature is that international price differences are larger for non-traded goods (such as services) and for goods and services with a high share of non-traded inputs (Crucini, Telmer and Zachariadis, 2005; ENGEL and Rogers, 1996). Furthermore, these studies demonstrate that price dispersion depends significantly on distance to the border region. This holds in particular for goods and, to a lesser extent, for services such as cinema tickets, taxis, and hotel rooms (Engel, Rogers and Wang, 2003; Crucini, Telmer and ZACHARIADIS, 2005).

The present paper is structured as follows. Section 2 introduces the empirical model, while Section 3 presents the data and descriptive statistics. Section 4 presents the empirical results, and Section 5 concludes.

\section{Empirical Model}

In order to investigate the determinants of ski lift tickets we adopt a hedonic price model. The theoretical basis is LANCASTER's (1971) theory of consumer demand and the hedonic price model introduced by Rosen (1974). In the Lancaster's model of consumer demand, goods and services can be viewed as bundles of attributes that consumers value. Rosen (1974) extended Lancaster's work by formulating market equilibrium conditions for the hedonic price regression. The assumptions are perfect competition, no significant transaction costs, correct measurement of all attributes and choice of the correct functional form. The model predicts that the outcome of all the independent decisions of the producers and consumers is an exact functional relationship between the price of the quality-differentiated good and the attributes embodied in that good. The 
market for ski destinations is assumed to be in equilibrium if skiers optimise their choice based on the lift ticket prices of alternative ski locations. Under the assumption of no search and information costs, the lift ticket prices of any ski resort can be described as a function of the resort's characteristics. These characteristics include size (i.e. length of ski runs and lift capacity), quality of ski lifts, average slope altitude, snowmaking capacity, age of resort and proximity to the nearest towns (Berwert, Bignasca and Filippini, 1996; Falk 2008; Borsky and RAsChKy, 2009). The characteristics vary considerably across countries based on the representative sample of ski resorts used in the study. For example, the average size of ski areas is much larger in France than in Austria and Switzerland, while Austria has a higher share of high-speed lifts and of slopes with snowmaking facilities (see Table 2). Swiss ski resorts are nearest and most accessible from the nearest towns, exhibits the highest average uphill lift station and have the longest history and most experience with winter sport tourism. Therefore, it is important to control for these characteristics when investigating lift ticket prices across countries.

We formulate a price equation in which lift ticket prices of any ski resort are described as a function of ski area characteristics and two country dummy variables:

$$
\ln P N_{i, t}=\alpha+\beta X_{i, t-1}+\gamma_{A T} A T_{i}+\gamma_{F R} F R_{i}+\varepsilon_{i, t},
$$

where $i$ denotes the ski area, $t$ refers to the winter season 2010/2011 and $t-1$ to the previous season, $P N_{i}$ is the price of a one-day lift ticket net of VAT (alternatively the price of a six-day lift pass), $X_{i}$ is a vector of characteristics, $\beta$ is the corresponding vector of coefficients, and $\varepsilon_{i}$ is error term. AT and FR are the country dummy variables, with Switzerland as the reference category. The coefficients on the two country dummy variables measure the average price difference relative to the base category. The percentage difference is simply obtained by $\left[\exp \left(\gamma_{k}\right)-1\right] * 100$, where $k=$ AT or FR. Note the price differential only gives an indication of the so called approximate absolute law of one price since no two ski areas are exactly identical even when a large number of characteristics are controlled for (Crucini, Telmer and Zachariadis, 2005; Broda and Weinstein, 2008). The partial derivative of the price equation with respect to ski area's characteristics gives the implicit marginal price of that characteristic.

Given the findings in the literature and the data availability, the price equation is specified as follows (e.g., Berwert, Bignasca and Filippini, 1996; FalK, 2008; BorsKy and RaschKy, 2009): 


$$
\begin{aligned}
\ln P N_{i, t} & =\alpha+\beta_{1} \ln \text { KM }_{i, t-1}+\beta_{2} \ln S V T M H_{i, t-1}+\beta_{3} Q U A L I T Y_{i, t-1} \\
& +\beta_{4} \ln A L T_{i, t}+\beta_{5} S N O W M A K_{i, t-1}+\beta_{6} \ln A G E_{i, t} \\
& +\beta_{7} \ln D I S T C I T Y_{i, t}+\beta_{8} D W C U P_{i, t} \\
& +\delta D N E T_{i, t}+\gamma_{A T} A T_{i}+\gamma_{F R} F R_{i}+u_{i, t},
\end{aligned}
$$

where $\ln$ is the natural $\log , i$ denotes the ski resort, and $u_{i}$ is the error term. The variables are as follows:

$P N$ : Price (net of VAT) of a one-day lift ticket for adults in the 2010-2011 peak season (which allows for guest card discounts granted to those staying at the resort), alternatively the price (net of VAT) of a six-day lift past for adults, $K M$ : Total length of slopes, in kilometres,

SVTMH: Total vertical lift capacity in persons per hour, measured as the sum of vertical transport metres per hour of each $\mathrm{lift}^{2}$,

QUALITY: Share of fast lifts (e.g. detachable chairlifts, modern gondola ropeways or MGDs, and funitel systems) in total transport capacity (i.e. vertical transport metres),

ALT: Weighted average altitude of peak lift stations (excluding t-bar lifts),

SNOWMAK: Share of ski runs with snowmaking facilities in per cent, $A G E$ : Age of ski area in years,

DISTCITY: Road distance to the nearest largest town in kilometres (with population of 50,000 or more),

DWCUP: Dummy variable whether or not ski resorts have been a venue of the FIS Alpine ski World Cup in the last 15 years (with 3 or more events), DNET Dummy variable for ski areas that are part of a greater ski network (usually not accessible with a one-day lift ticket but with a six-day lift pass), $A T$ and FR: Dummy variables for Austria and France.

The dependent variable is measured as a one-day lift ticket. Alternatively, we use the six-day ski pass. Note that multiple-day tickets often cover a wider geographical area with access to several other ski areas. One-day lift tickets usually only give access to one (often lift-linked) ski area and/or one section of the wider ski area. Some small ski areas that are part of large ski alliance do not offer a six-day lift pass for the part of the ski area but only a multi-area ski pass. This ski resorts have to be excluded from the sample.

2 Ski lifts include t-bar and surface lifts; fixed and detachable chairlifts; aerial tramways; gondola ropeways, such as MGDs; and funitel systems. 
Turning to the independent variables, we account for the size of the ski areas, which is one of the most important characteristics. Size is measured by two indicators. First, we use the total length (in kilometres) of ski runs; larger ski resorts typically charge higher prices. Second, we include lift capacity weighted by vertical transport metres. A greater lift capacity is obviously more valuable to skiers because it reduces the time spent in the queue waiting for the ski lift and makes the ski area more attractive (Müller and Michel, 2001). To measure lift capacity, we first calculate the vertical transport metres per hour for each lift: $V T M H=(\mathrm{CAP} \times V M) / 1000$, where $C A P$ denotes the capacity in skiers per hour and $V M$ denotes the vertical rise in metres. This is a measure of lift capacity that multiplies passengers per hour by vertical distance to determine how many people can be transported uphill at approximately 1,000 metres per hour. For each ski resort, we calculate the sum of vertical transport metres per hour (SVTMH):

$$
S V T M H=\sum_{j=1}^{J} V T M H_{j},
$$

where $j$ denotes the ski lift, regardless of type (this includes surface lifts; fixed and detachable chairlifts; aerial tramways; gondola ropeways, such as MGDs; and funitel systems).

Previous empirical work indicates that adoption of new technologies are the key factor for productivity and performance at the firm level (see e.g. BRYNJOLFsson and Hitt, 2003). Mulligan and Llineares (2003) find that early adoption of new technologies (e.g. detachable chairlifts) has allowed firms to charge higher prices. New and fast lifts facilitate the transportation of a large number of skiers with shorter riding times, thus reducing queues. We expect a high share of modern chairlifts and gondolas to have a positive effect on ski lift ticket prices. This share is measured as the ratio of vertical transport metres per hour of modern high-speed lifts and cable cars to total vertical transport metres per hour. Fast lifts include fast and detachable chairlifts, modern gondola ropeways (e.g. monocable gondola detachables), and funitel systems, but excludes the transport capacity of surface lifts, fixed-grip chairlifts, and aerial tramways.

Snow is the most essential input factor for skiing. However, data for snowfall or snow depth at the resort level are only available for half of the sample. Furthermore, average slope height is important for snow conditions because snow is less affected by high temperatures and lasts longer at high altitudes. In order to measure average slope height, $A L T$, we calculate the weighted average of the uphill lift stations for each ski area, where the weights are the share of the capacity of 
each lift in the ski area's total lift capacity (measured as vertical transport metres per hour).

Snowmaking can also be an effective means of compensating for a poor natural snow record. Snowmaking capacity is measured by the percentage of ski runs with snowmaking facilities. It may well be the case that snowmaking capacity is more valuable in low-altitude ski areas. Indeed, preliminary estimates show that snowmaking only shows the expected positive sign for low-altitude ski resorts. Therefore, we include an interaction term between snowmaking capacity and the average altitude of uphill lift stations.

Furthermore, older ski areas may set higher prices because of a good reputation and brand name. It is often hypothesized that the longer a firm has been in operation, the more productive it will become. This is often referred to as the "learning by doing" or "learning curve" effect (BAHK and GORT, 1993). Ski resort age is measured as the number of years in operation.

Some ski resorts have been traditional venues of the annual FIS alpine World Cup (e.g. Chamonix, Kitzbühel, Sölden, St. Moritz, Val d'Isère, Wengen). It is obvious that hosting ski races on a regular basis increase the publicity of the resort and tourism demand after the events. As an alternative measure of reputation we use information whether or not the ski resorts have been venues for the FIS World Cup in the last 15 years. ${ }^{3}$ Ski resorts that are only occasionally venues of the FIS World Cup are not included in the group of World Cup venues. Events and tourist attractions during the summer period might also increase the overall image of the ski resort. However, for the summer period data for visits at the detailed resort level for all three countries are not readily available.

The attractiveness of ski areas also depends on whether they are connected by ski bus to other ski resorts that are accessible with the same ski pass. For instance, Ski Arlberg (AT), Les Portes du Soleil (F/CH), Espace Killy (F), Paradeski (F), St. Moritz $(\mathrm{CH})$, Davos $(\mathrm{CH})$, Quatre vallées $(\mathrm{CH})$, trois vallées $(\mathrm{F})$, and ski amadé (AT) all offer a multi-area ski pass that is valid at all of their ski locations. These interlinked ski areas are connected either by a free shuttle bus service or lifts. These effects will be captured by the dummy variable indicating linked ski resorts. However, neighbouring ski resorts that are part of a greater ski network are usually not accessible with a one-day lift ticket. Despite this, we include geographical dummy variables for the ski areas that are part of ski alliances because of their potentially increased destination marketing, promotion efforts, and brand name.

3 I am grateful to an anonymous referee for this suggestion. 
Furthermore, distance to the nearest town is expected to have a significant and negative impact on lift ticket prices. This means that ski resorts that are farer away from the nearest regional town exhibit lower prices. Distance to the nearest town is an indicator for local accessibility via transportation networks. In particular, for day trippers travel time is of critical importance. Ski resorts in close proximity to regional centres have clearly an advantage because of local market potential. BERWERT et al. (1996) find that proximity to population centres is significantly positively related to ski lift prices based on 84 Swiss ski resorts for the season 1992/1993. We use road distance to the nearest regional town with a population of at least 50,000 following Eurostat's definition of agglomerations.

Distance to the nearest border may also affect lift ticket prices (LI, Gopinath, Gourinchas and Hsieh, 2010). Price differences in absolute terms are expected to increase with the distance of the nearest border ski area. Li, Gopinath, Gourinchas and Hsieh, (2010) suggest that it is important to investigate the price differences in goods and services sold that are located immediately across the border rather than at a greater distance. In the following, we extend the baseline specification by including distance to the nearest border ski area and an interaction term between distance and the country dummy variables:

$$
\begin{aligned}
\ln P_{i, t}= & \alpha+\beta X_{i, t-1}+\gamma_{A T} A T_{i}+\gamma_{A T} F R_{i} \\
& +\delta_{1} A T_{i} \cdot D_{i}+\delta_{2} F R_{i} \cdot D_{i}+\chi D_{i}+u_{i, t},
\end{aligned}
$$

where $D$ is the road distance (in kilometres) between a given ski area and the nearest border ski area. We define distance as positive for Swiss ski areas and negative for Austrian and French ski areas. Following Li, Gopinath, Gourinchas and Hsien (2010), we estimate the price equation for ski areas within a certain distance to the border (in this case, $200 \mathrm{~km}$ ).

There are a few factors that cannot be controlled for because they are difficult to measure or data are not readily available. These factors include friendliness and atmosphere, safety aspects, and attractive views and natural surroundings, preparation of runs and ski slope grooming, and hygiene in toilets (MüLLER and Michel, 2001). Other factors that are related to the infrastructure include the availability of carpet lifts ("magic carpets") that are especially suitable for beginners and children, the presence of snow parks with half pipes and rails as well as off-piste terrain. These factors all increase the attractiveness of the ski resort. Finally, snow conditions in the past winter seasons is also an important factor in selecting ski resorts. Travel behaviour depends not only on past snow conditions but also on average temperatures and sunshine. Most skiers and snowboarders 
prefer sunny weather and pleasant temperatures. However, weather data is only available for half of the sample resorts.

The price equation can be estimated by OLS. In order to investigate whether there are differences in the coefficients at different points in the conditional distribution, we apply quantile regressions (see Koenker and Hallock, 2001). The main hypothesis is that the determinants of lift ticket prices differ between low- and high-priced ski areas. Indeed, previous studies often show considerable parameter heterogeneity at different points in the conditional distribution of the left-hand variable. The quantile regression method allows one to focus on specific parts of the distribution of conditional prices and is suitable for detecting differences in the determinants of lift ticket prices at various quantiles (KOENKER and Hallock, 2001). For a given cross-section, the quantile regression model can be written as

$$
\begin{aligned}
& P N_{i, t}=Z_{i, t-1}^{\prime} \beta_{\theta}+u_{\theta i} ; \\
& Q_{\theta}\left(P N_{i, t} \mid Z_{i, t-1}\right)=Z_{i, t-1}^{\prime} \beta_{\theta},
\end{aligned}
$$

where $P N$ denotes $\log$ net prices and $Z$ the vector of explanatory variables. $\beta$ is the vector of parameters to be estimated for a given value of the quantiles $Q$. $Q_{\theta}\left(P N_{i, t} \mid Z_{i, t-1}\right)$ is the $\theta$-th quantile of the conditional distribution of prices given the vector of explanatory variables $Z$. The estimation of the quantile parameters can be done by solving a minimization problem where the corresponding residuals have to be weighted. For $\theta=0.5$, the median is obtained and the least absolute deviation estimator can be employed. Standard errors are obtained by using the bootstrap method with 1,000 repetitions (see Gould, 1997). Another advantage of the quantile regression technique is that it is consistent and robust when the error term is heteroscedastic and non-normally distributed. Given the relatively small sample of 214 observations, we estimate quantile regressions for the $0.25,0.5$, and 0.75 quantiles only.

\section{Data and Descriptive Statistics}

We create a representative sample of 214 ski resorts in Austria, France, and Switzerland. According to the selection criteria, all ski resorts with a length of slopes of $50 \mathrm{~km}$ or more are included. For the group of resorts with 20 to $50 \mathrm{~km}$, we use a random sample (for a list of the included ski areas, see Table 8 in the appendix). Data on one-day and six-day lift tickets is obtained directly from the websites 
of the ski lift companies (accessed September 2010). Note that lift tickets vary with skier age and seasons. Here we focus on lift ticket prices for adults in the peak season. Ski lift ticket prices have been adjusted for VAT differences; the net price, $P N$, is obtained by the gross price $P$ divided by 1 minus the tax rate $V$ : $P N=P /(1+V / 100)$. In the next step, lift ticket prices in Swiss francs are converted into Euros using the corresponding exchange rate from the three months between June and August 2010 which is CHF 1.36/1€. This is because lift ticket prices for the upcoming season are usually set during the summer period. Furthermore, we take into account that some ski resorts offer discounts to guests who are staying overnight. However, only a few resorts give discounts on one-day lift tickets and six-day ski passes to overnight guests. More importantly, in Switzerland there are discounted lift tickets available. The Swiss Federal Railways (SBB) offer a combined ticket for public transport (train and bus) and lift tickets with a considerable discount. This so-called "Snow'n'Rail" ticket is available for all major ski resorts and consists of a discounted train ticket from any Swiss station and the return trip combined with 20 per cent reduction for either a one-day or a two-day lift ticket. ${ }^{4}$ Discounts are also available for six-day passes but limited to 12 ski resorts. The availability of discounts on one-day lift tickets complicates the price comparison across countries. Therefore, it might be more appropriate to compare six-day lift passes rather than one-day lift tickets since only few resorts offer discounts on six-day lift tickets (combined with a public transport ticket). While there are significant discounts on lift tickets in Switzerland, discounts on lift tickets are hard to find in Austria and France.

We draw our ski area information from a number of sources. The information on lift characteristics and resort attributes comes mainly from official sources (see Table 1 for a description of the data sources). Generally, the lift databases are very detailed, including information on mountain lift capacity in persons per hour, vertical drop in metres, year of installation, and altitude of the highest lift station. Mountain lift systems include detachable chairlifts (carriers for two, four, six, or eight passengers), fixed-grip chairlifts (carriers for one, two, four, or six), funitel systems, and MGD gondola lifts, as well as aerial ropeways and surface lifts (such as T-bars). We carefully checked the data from these various sources to ensure accuracy and reliability. Road distance to the nearest town with 50,000 or more inhabitants is calculated from the centre of the city to the centre of the ski resort and measured in kilometres. If the closest town is located in another country (e.g. Germany) the road distance to that city is used.

4 See the homepage of the Swiss Federal Railway (www.railaway.ch/snow-n-rail/). 
Table 1: Description of the Data Sources

Price of one-day lift ticket for adults $(€)$; total length of ski runs $(\mathrm{km})$;

percentage of slopes with artificial snowmaking facilities (\%).

Lift capacity measured as vertical transport metres in persons per hour divided by 1000 ; share of detachable chairlifts, detachable cable cars and funitels (\%); weighted mean altitude of uphill lift stations $(\mathrm{m})$. web sites of individual ski resorts web sites of individual ski resorts and/or personnel correspondence F: ski magazines: Montagne Leaders varies issues, ADAC Ski-Atlas, DSV-Atlas various issues website www.bergfex.com.

AT: (i) BMVIT 2001/2002 cable car database (Seilbahnstatistik),

Amt der Tiroler Landesregierung (ii) „Seilbahnen, Lifte in Tirol 2009/2010“ "Cable Cars and Chairlifts in Tyrol”) and "Seilbahnen, Sessel- und Schlepplifte in Vorarlberg 2010“ ("Cable Cars and Chair- and T-Bar Lifts in Vorarlberg").

$\mathrm{CH}$ : Swiss ministry of transport and regional development.

FR: «Fichier Informatisé des appareils de Remontées Mécaniques, Ministère des Transports, de l'Equipement, du Tourisme et de la Mer». Available at the internet from: http://firm.application.equipement.gouv.fr/ FirmInternetAction.do?choix=Init retrieved September 2010.

Online Lift database www.remonteesmecaniques.fr; retrieved May 2010.

AT, CH, FR: "Online database for Alpine Ski resorts", Retrieved October 2010 (http://www.lift-world.info/english.php).

Table 2 presents the summary statistics on the variables for the sample used in the subsequent regressions. We report the means and medians for each of the three countries separately. The average one-day lift ticket prices net of VAT for the winter season 2010/2011 range between $€ 32.60$ in France and $€ 36.10$ in Switzerland, with Austria in between at $€ 33.30$. When the median is used, the differences are even more pronounced: $€ 30.60$ in France, $€ 33.90$ in Austria, and $€ 35.20$ in Switzerland. The average six-day lift ticket price net of VAT is $€ 159$ in Austria, $€ 165$ in France and $€ 173$ in Switzerland.

Regression results show that these international price differences are significant at the 5 per cent level, even when the characteristics are not included. This holds both for gross and net prices and for the OLS and median regression results (see 


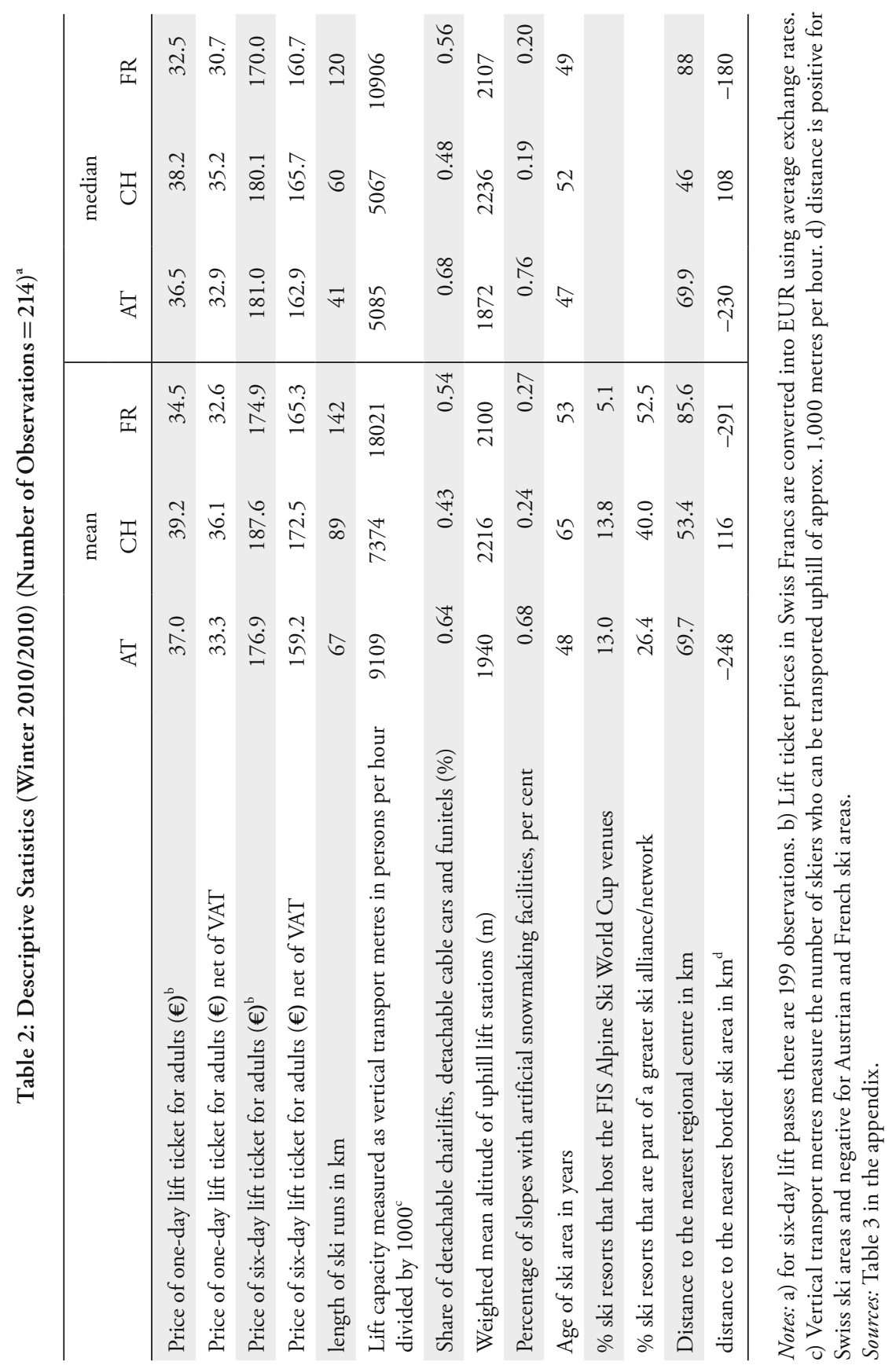


Table 3). Overall, the two country dummy variables explain 9 per cent of the variation in gross lift ticket prices (including VAT) as indicated by the R squared. When lift ticket prices are measured as the six-day ski pass price differences are much less pronounced.

Table 3: OLS and Median Regression Estimates of the Lift Ticket Differences across

\section{Countries}

\begin{tabular}{|c|c|c|c|c|}
\hline & \multicolumn{2}{|c|}{ log gross } & \multicolumn{2}{|c|}{$\log$ net } \\
\hline & coeff. & $t$-value & coeff. & $t$-value \\
\hline \multicolumn{5}{|l|}{ one-day ski lift ticket } \\
\hline & \multicolumn{4}{|c|}{ OLS estimates } \\
\hline Dummy variable Austria & $-0.050^{* *}$ & -2.03 & $-0.073^{* * *}$ & -2.93 \\
\hline Dummy variable France & $-0.132^{* * *}$ & -3.98 & $-0.106^{* * *}$ & -3.18 \\
\hline Constant & $3.654^{* * *}$ & 170.63 & $3.571^{* * *}$ & 166.16 \\
\hline \multirow[t]{2}{*}{$\mathrm{R}^{2}$} & 0.090 & & 0.060 & \\
\hline & \multicolumn{4}{|c|}{ Median regression estimates } \\
\hline Dummy variable Austria & -0.046 & -1.52 & $-0.068^{* *}$ & -2.03 \\
\hline Dummy variable France & $-0.163^{* * *}$ & -3.72 & $-0.136^{* * *}$ & -3.01 \\
\hline Constant & $3.644^{* * *}$ & 153.1 & 3.560 & 131.91 \\
\hline \multicolumn{5}{|l|}{ six-day ski pass } \\
\hline & \multicolumn{4}{|c|}{ OLS estimates } \\
\hline Dummy variable Austria & -0.038 & -1.28 & $-0.060^{* *}$ & -2.03 \\
\hline Dummy variable France & $-0.070^{* *}$ & -2.17 & -0.043 & -1.33 \\
\hline Constant & $5.216^{* * *}$ & 224.47 & $5.133^{* * *}$ & 220.88 \\
\hline \multirow[t]{2}{*}{$\mathrm{R}^{2}$} & 0.094 & & 0.028 & \\
\hline & \multicolumn{4}{|c|}{ Median regression estimates } \\
\hline Dummy variable Austria & -0.038 & -1.25 & 0.005 & 0.16 \\
\hline Dummy variable France & $-0.070^{*}$ & -1.93 & -0.058 & -0.97 \\
\hline Constant & $5.216^{* * *}$ & 197.5 & $5.194^{* * *}$ & 181.0 \\
\hline
\end{tabular}

Notes: Median regressions with bootstrapped standards errors and 1000 replications. Significance at the 1,5 or $10 \%$ level is denoted by ${ }^{* * *},{ }^{* *}$ and ${ }^{*}$, respectively.

Obviously, the ski areas differ significantly in their characteristics across countries. French resorts are larger on average than their competitors in Austria and Switzerland in terms of length of slopes and transport capacity. In particular, the average length of ski runs is $40 \mathrm{~km}$ in Austria, $120 \mathrm{~km}$ in France, and $105 \mathrm{~km}$ 
in Switzerland. Average lift capacity is highest in France, with 10,906 on average (indicating the capacity to transport 10,906 skiers up a mountain of about 1,000 vertical metres every hour). Swiss resorts are older and have higher skiarea altitudes. Specifically, the mean altitude of peak lift stations (i.e. uphill cable and chairlift terminals) is highest in Switzerland with 2,236 metres on average, followed by France with 2,107 metres and Austria with 1,872 metres. Austrian ski areas have a greater snowmaking capacity and the greatest share of fast lifts. In particular, the share of high-speed (detachable) chairlifts and modern gondola lifts in total lift capacity is 68 per cent on average in Austria, followed by France with 56 per cent and Switzerland with 48 per cent. In Austria, snowmaking facilities are in place on 68 per cent of the runs on average, as compared to about 24 and 27 per cent in France and Switzerland, respectively. Furthermore, the average distance to the nearest regional population centre is lowest in Switzerland with 53 kilometres, followed by Austria with 69 kilometres on average and France with 88 kilometres on average.

\section{Estimation Results}

\section{OLS and Quantile Estimation Results}

Table 4 presents OLS estimates of the log-linear price equation for both one-day and six-day lift tickets net of VAT, where the t-values are based on heteroscedasticity-consistent standard errors. Overall, the fit of the OLS model is quite good, with an adjusted $\mathrm{R}^{2}$ of 0.75 for one-day lift tickets and 0.66 for six-day ski passes. Specification (i) contains the estimates of the basic price equation, whereas specification (ii) contains the results of the price equation with an interaction term between snowmaking capacity and altitude of uphill lift stations. The interpretation focuses on specification (ii) because the interaction term is highly significant, indicating that the impact of snowmaking is significantly positive, but decreases with increasing ski-area altitude.

The results for the cross-country effects show that the country dummy variable for France is negative and significant when the different characteristics are accounted for, implying that one-day lift ticket prices in France are an average of 17 per cent lower than those in Switzerland (percentage difference is obtained by: $(\exp (-0.19)-1) * 100)$. The corresponding price gap for Austria is 7.5 per cent. For six-day ski passes we find that the price differential is less pronounced but still significant with in France 14 per cent and Austria 9 per cent lower prices on average than those in Switzerland. This may indicate that consumers are willing 
to pay a substantial price premium for Swiss ski areas as compared to French ski areas with similar characteristics (e.g. size and quality of lifts, snowmaking capacity). It is interesting to note that the price differences between French and Swiss ski resorts are much lower in absolute terms when the characteristics are not included. In particular, the difference between Swiss and French one-day lift ticket prices decreases from 17 per cent to 10 per cent when the characteristics are excluded (compare Table 4 with Table 3). The corresponding change for sixlift tickets is from 14 per cent to 4 per cent, respectively. This can be explained by the fact that French resorts are much larger on average in terms of lift capacity and total length of ski runs.

Furthermore, unreported results show that one-day lift ticket prices in France and Austria are 19 per cent and 5.2 per cent lower, respectively, than those in Switzerland when lift ticket prices (including VAT) are used. Differences in the VAT rates thus only explain a small portion of the price differences across countries. This is consistent with the Commission (2002), which finds that differences in VAT rates are not a major cause of the price dispersion in supermarket goods across countries.

The characteristics are all significant and show the expected sign. In particular, capacity of mountain lift systems and average altitude of uphill lift stations are significant at the 1 per cent level. Length of slopes is positive, but only marginally significant. Furthermore, the share of fast chairlifts and modern cable cars in total lift capacity is positive and statistically significant at the 1 per cent level. The coefficient of 0.20 translates into an elasticity of $0.11(=0.55 * 0.20)$. There is no significant relationship between lift ticket prices and the percentage of slopes covered by artificial snow based on specification (i). However, the interaction term between percentage of slopes covered by artificial snow and altitude of uphill lift stations shows that snowmaking capacity has a significant and positive impact on lift ticket prices at lower-altitude ski areas (with uphill lift stations at an average of 2,060 metres or lower; see Figure 1). For instance, the coefficient is 0.13 for ski resorts with uphill lift stations at an altitude of around 1,500 metres, indicating that an increase in the share of snowmaking capacity by 10 percentage points (from the sample mean of 0.43 to 0.53 ) would raise the price level by 1.3 per cent. Furthermore, older ski areas charge significantly higher lift ticket prices, indicating that older resorts have a better reputation because they are well known; in the market, however, this may also be due to an early-mover advantage. In addition, older ski areas are often characterised by a high-quality infrastructure (such as public transport systems). Besides resort age, hosting FIS Alpine World Cup events is significantly positively related with lift ticket prices. The price differential between ski resorts that hosts World Cup races and the 


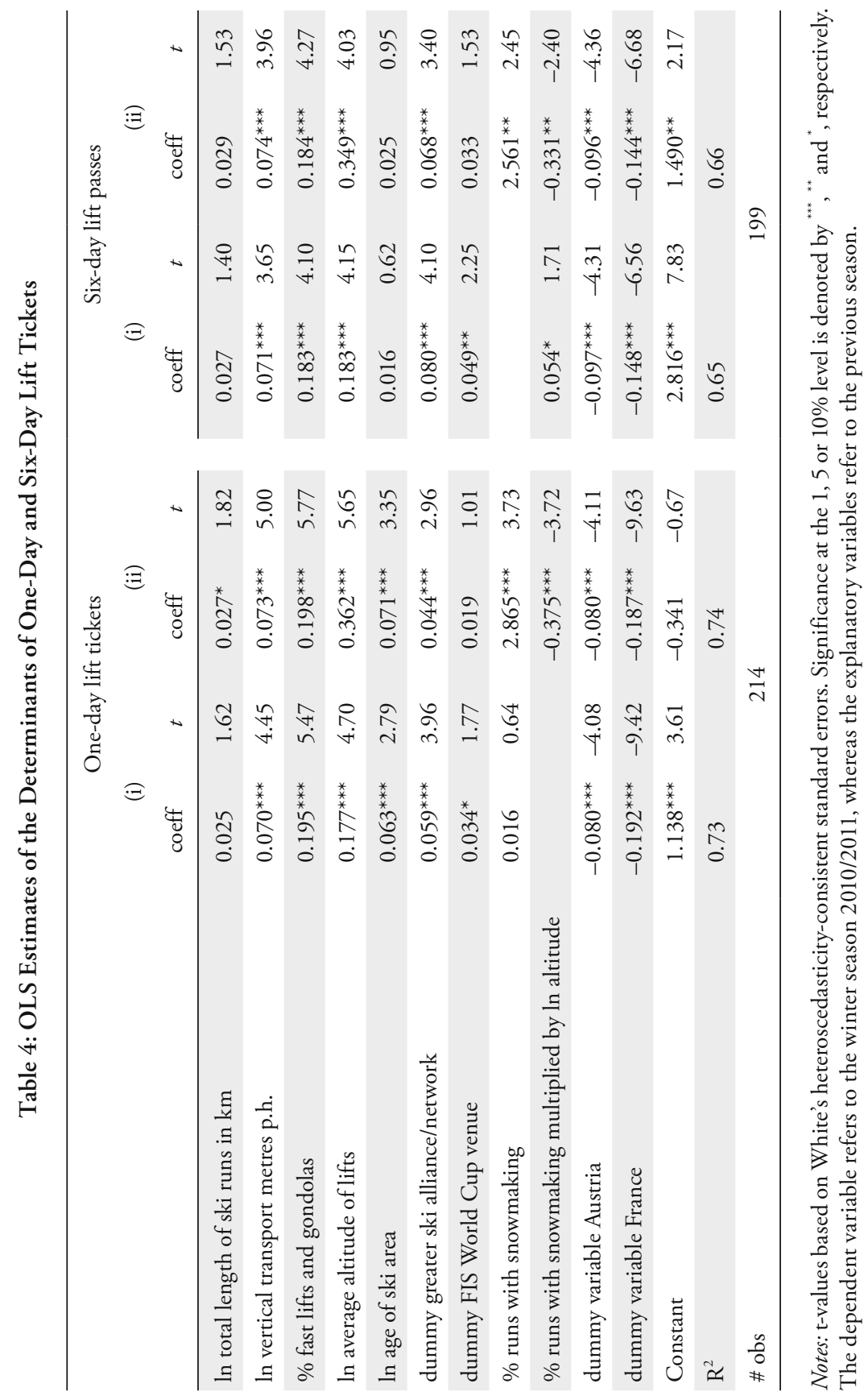


remaining ski resorts is about 3 per cent for one-day lift tickets and 5 per cent for six-day lift tickets on average. However, the coefficient is no longer significant when the interaction term between percentage of runs with snowmaking facilities and altitude of the uphill lift stations is included. Finally, ski resorts that are part of a greater ski network or alliance charge higher prices. Note that one-day lift tickets usually restrict access to a single ski area.

Figure 1: Impact of Snowmaking on the One-Day Lift Ticket Price by Altitude

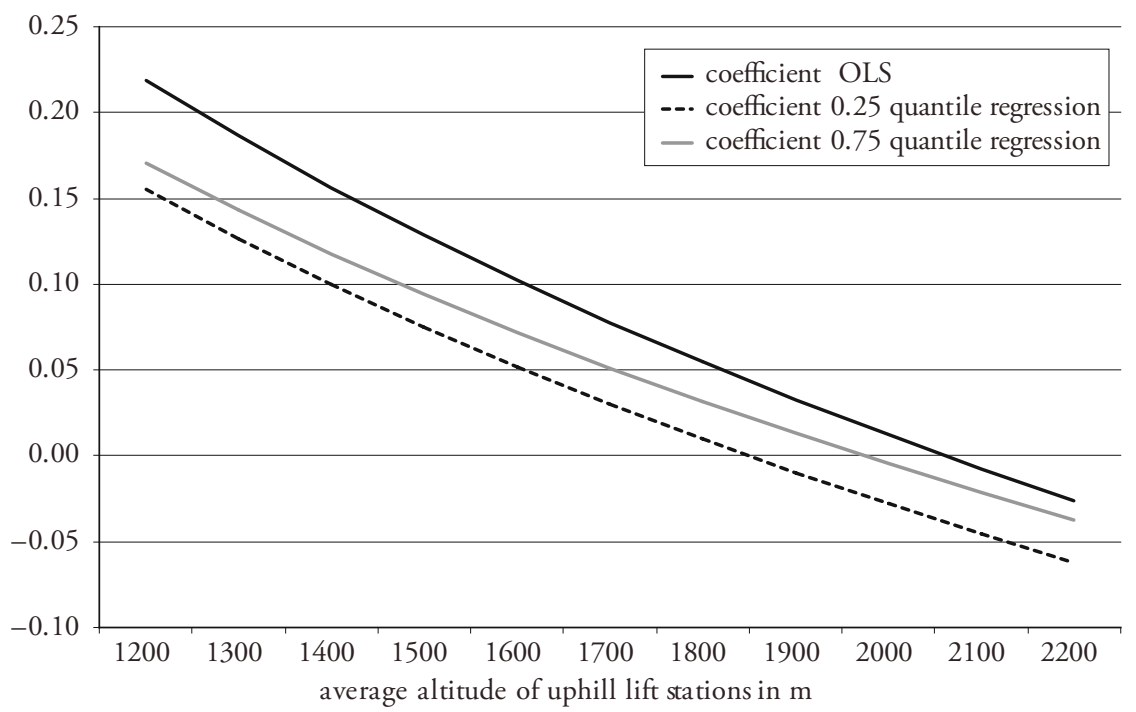

Notes: Quantile regressions with bootstrapped standards errors and 1000 replications.

Overall the results are consistent with the previous literature. Based on representative sample of Swiss ski resorts, BERWERT et al. (1996), find that ski lift ticket prices are significantly positively related to lift capacity, quality of the ski facilities (i.e. share of chairlifts and gondolas in total lift capacity) and the average altitude of the ski resorts. However, snowmaking capacity is not significantly different from zero. Based on a similar data set for Austria, FALK (2008) find that lift ticket prices depend on lift capacity and speed of lift facilities, length of ski runs, altitude of uphill lift stations and percentage of slopes covered by snowmaking machines. 
Some variables are not included in the regression because they are not significantly related to lift ticket prices. These variables include the longest downhill valley run, average age of lift facilities, and the length of the planned ski season. Surprisingly, the coefficient of log road distance between the ski resort and the nearest town is not significant (see Table 5). In general, one would expect that the distance coefficient is negative indicating that ski resorts that are farer away from the nearest town have lower lift ticket prices. However, different specifications show that distance is positive although it is not significantly different from zero. When we include both the logarithm of distance and its squared term we again find that both variables are not significantly different from zero (based on a Wald test of joint significance). The sign of coefficient of log distance is positive while the sign of the coefficient of its squared term is negative (although not significant) indicating an inverted $\mathrm{u}$-shaped relationship. As an additional robustness check we split the road distance variable into a set of dummy variables $(0$ for a distance of $45 \mathrm{~km}$ or less, 1 for between $45 \mathrm{~km}$ and $65 \mathrm{~km}, 2$ for between $65 \mathrm{~km}$ and $90 \mathrm{~km}$ and 3 for $90 \mathrm{~km}$ and more). We find that lift ticket prices are higher for ski resorts that located between 45 and 65 kilometres but the coefficient is only marginally significant. One explanation of the insignificance of distance might be that very small ski resorts are not included in the sample because of data availability. Similarly, unreported results show that (road) distance to the nearest international airport does not significantly influence prices. The previous literature on the role of distance from the nearest population centre seems to be not clear-cut. Using data for Scottish ski resorts, RidDington et al. (2000) find that the choice of ski resorts destinations is independent of the distance to individual 'place of residence. For Swiss ski resorts, Berwert et al. (1996) find that proximity to population centres is positive and significant in three out five specifications. Mulligan and Llinares (2003) use the number of population closely adjacent to ski resorts as measure of the local market and accessibility. Based on 344 ski resorts in the U.S, the authors find that the number of population within 125 miles has a positive effect on ski lift prices.

In the next step, we provide the results of quantile regressions for the 0.25 , 0.5 , and 0.75 quantile in order to investigate whether the influence of ski resorts' characteristics is different for low- and high-priced ski areas (see Table 6).

Quantile regressions for the $25^{\text {th }}$ and $75^{\text {th }}$ conditional percentile show that the price differential across countries holds for both high-price/high-quality and lowprice/low-quality ski areas. However, there are some notable differences between the estimated effects at the mean and those estimated for ski resorts with the highest and lowest (conditional) lift ticket prices. In particular, we find that the impact of the share of fast lifts decreases between the 0.25 to the 0.75 quantile. 


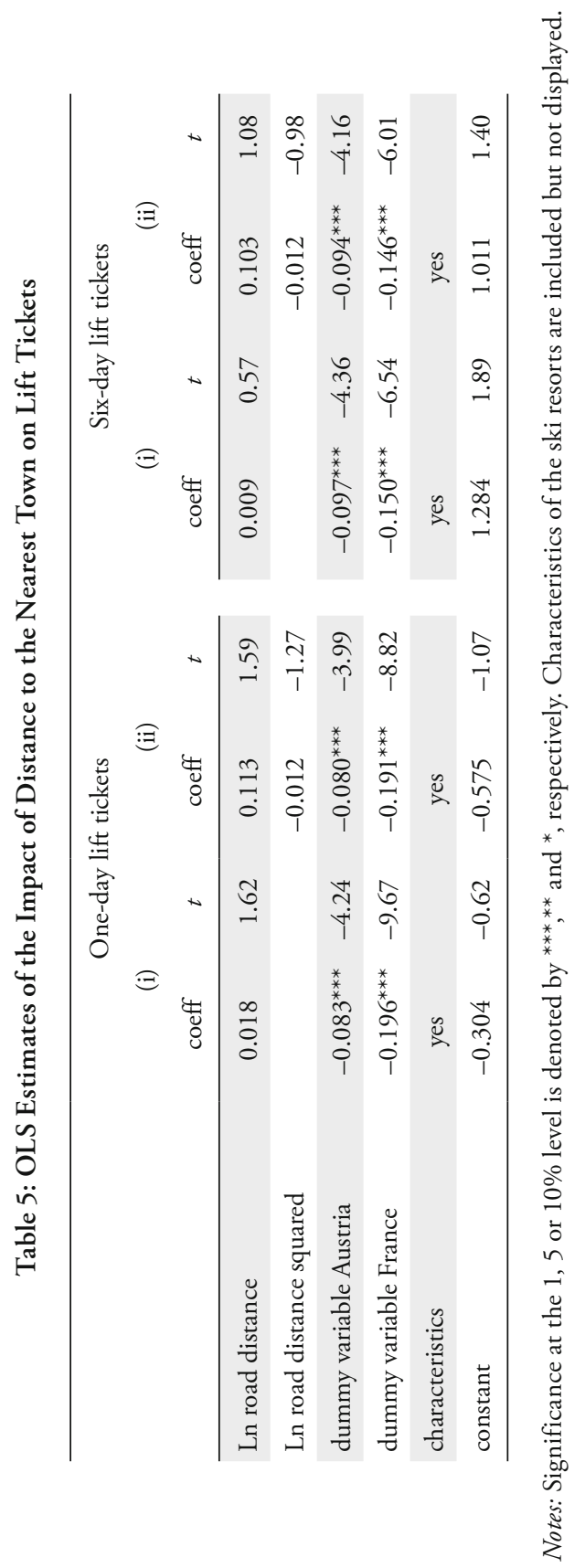


Table 6: Quantile Estimates for the Determinants of One-Day and Six-Day Lift Tickets

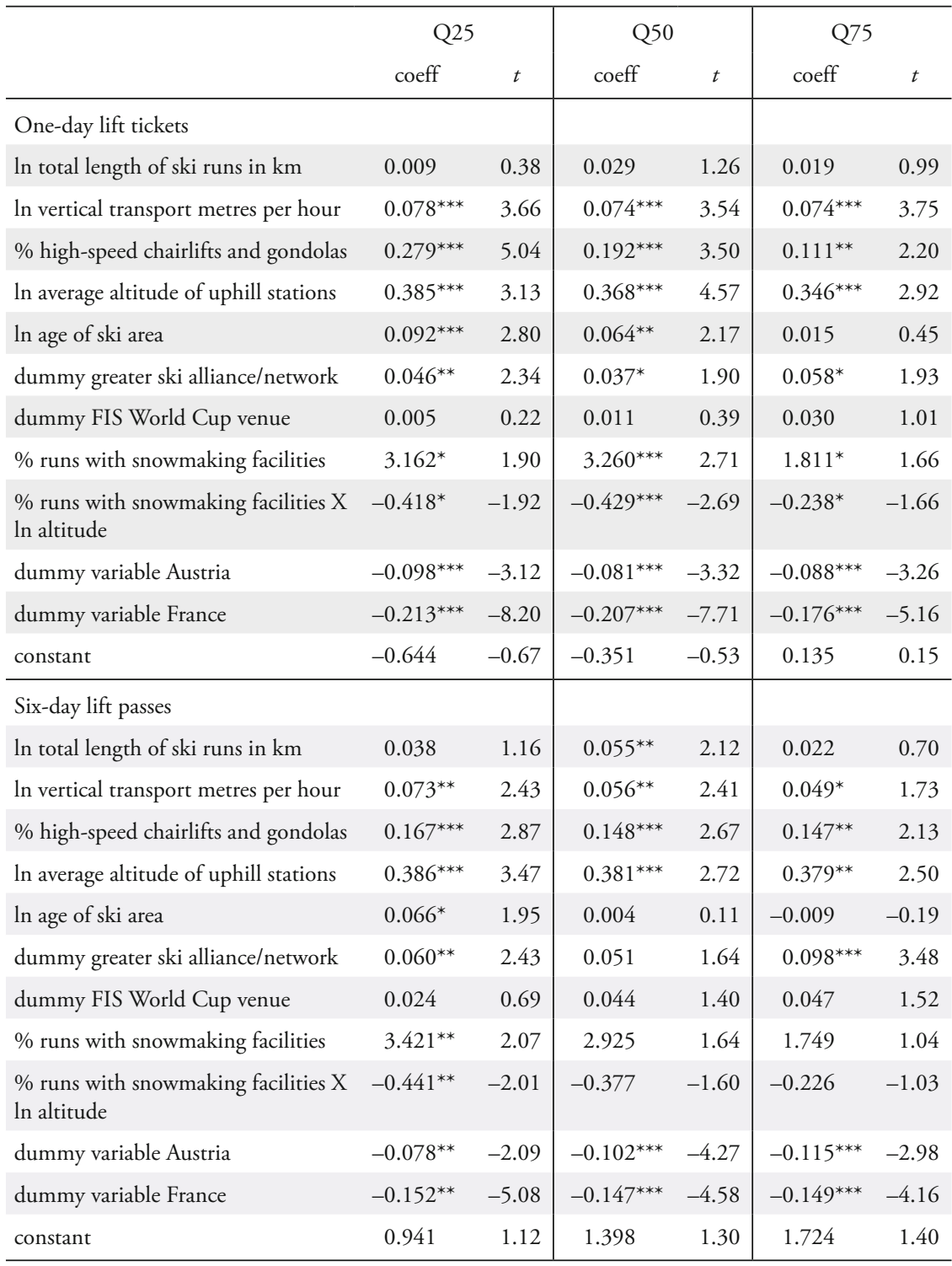

Notes: Quantile regressions with bootstrapped standards errors and 1,000 replications. Significance at the 1,5 , or $10 \%$ level is denoted by ${ }^{* * *}$, ${ }^{* *}$ and ${ }^{*}$, respectively. Q25, Q50, and Q75 denote quantile regressions at the $0.25,0.5$, and 0.75 quantile. 
This indicates that since consumers are willing to pay higher lift ticket prices for fast lifts, investing in fast new lifts is more valuable for low-price/low-quality ski resorts. For high-priced ski areas resort age is also not significant. Furthermore, we find that vertical transport metres, average altitude, and snowmaking capacity do not vary much over the different quantile regressions.

Finally, we investigate whether price differences increase with distance to the border. Figure 2 shows the relationship between the predicted lift ticket prices and the distance to the nearest border ski resort. We provide separate graphs for two estimation samples, one including Austrian and Swiss ski areas and the other including French and Swiss ski areas, where the sample is restricted to all ski areas within 200 kilometres or less of the nearest border ski resort. The results are not clear cut. Overall, it seems that the number of observations is still too small to make strong statements about the type and functional form of the relationship.

Table 7 provides further evidence as to whether price differences increase with distance to the border. The interaction term between French ski areas and distance to the nearest border ski area is negative, indicating that the price difference in absolute terms decreases as distance to the border increases. However, the interaction term between Austrian ski areas and distance to the nearest border resort is not significant, indicating that price differences do not depend on the distance.

We estimate several extensions and robustness checks of the basic price equation. First, we estimate the price regression using a robust regression technique, which is an iterative, weighted least-squares procedure that puts less weight on outliers. However, the magnitude and the significance level are similar to those of the OLS estimates. Second, we re-estimate the price equation including other interaction terms of the explanatory variables. However, unreported results show that adding interaction terms to allow for the heterogeneity of the effects does not improve the explanatory power of the price equation in most of the cases. Third, we account for spatial dependence because the prices of neighbouring areas are more likely to be similar to each other than to distant areas. However, the coefficient of spatially lagged prices is never significant when the dummy variable for being part of a greater ski network is controlled for. Fourth, the regressions provided treat each ski area equally. One may argue that larger ski areas should have a higher weight. When the regression is re-estimated using weighted least squares where the weights consist of lift capacity, we find that the results are almost identical. 
Figure 2: Predicted Lift Ticket Prices and Distance to the Border
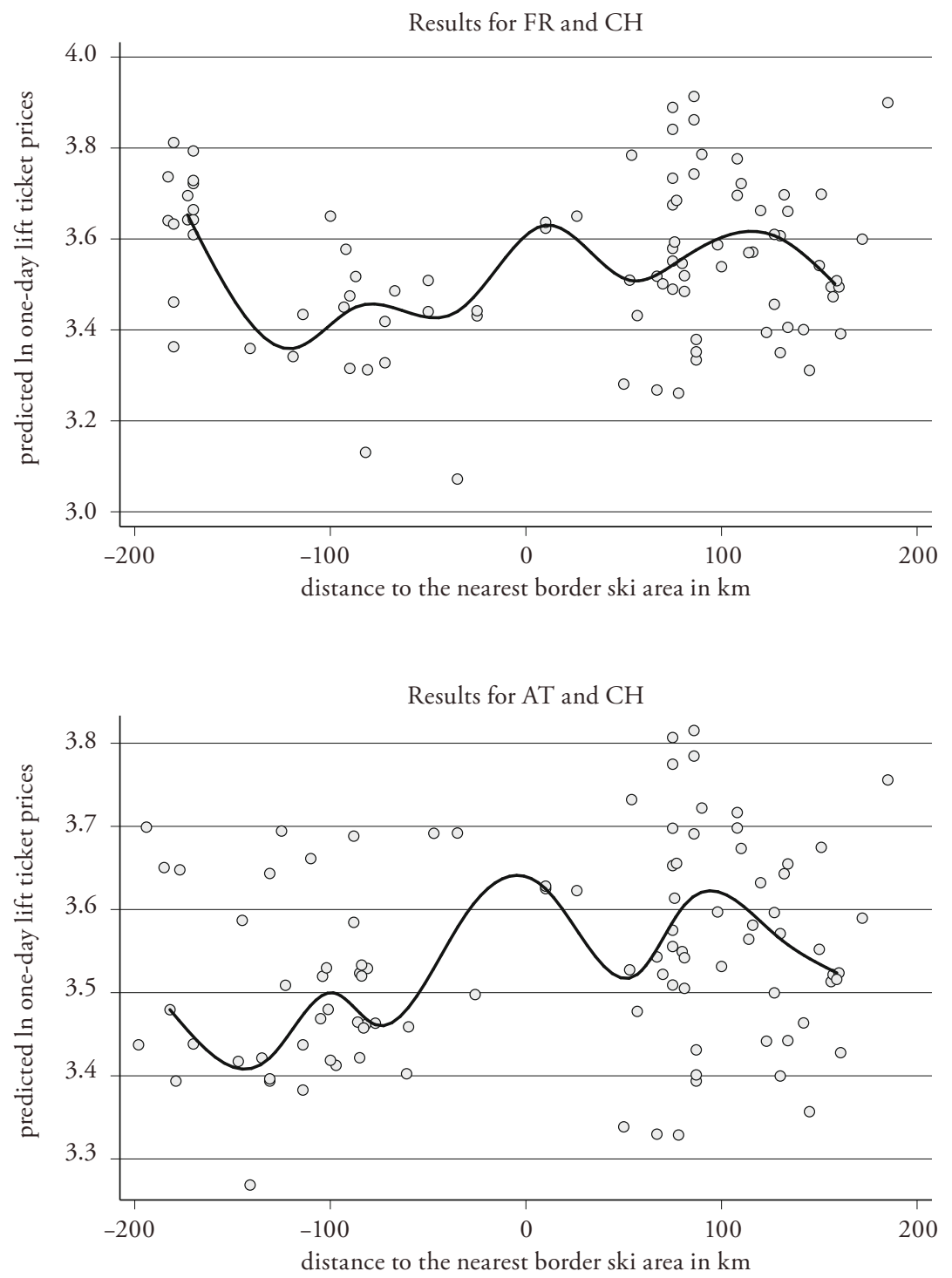

Notes: The solid line represents a cubic spline function where the knots are based on cross medians. 


\section{Table 7: OLS and Median Regression Estimates of the Impact of Border Distance on Lift Ticket Differences across Countries}

\begin{tabular}{|c|c|c|c|c|}
\hline & \multicolumn{2}{|c|}{ OLS estimates } & \multicolumn{2}{|c|}{$\begin{array}{c}\text { Median regression } \\
\text { estimates }\end{array}$} \\
\hline & coeff. & $t$-value & coeff. & $t$-value \\
\hline In total length of ski runs in $\mathrm{km}$ & 0.022 & 0.94 & 0.007 & 0.22 \\
\hline ln vertical transport metres per hour & $0.083^{* * *}$ & 3.86 & $0.082^{* * *}$ & 2.82 \\
\hline $\begin{array}{l}\text { share of high-speed chairlifts and gondolas } \\
\text { in per cent }\end{array}$ & $0.253^{* * *}$ & 5.96 & $0.247^{* * *}$ & 3.63 \\
\hline $\begin{array}{l}\text { In average altitude of uphill stations in } \\
\text { metres (ALT) }\end{array}$ & $0.373^{* * *}$ & 3.79 & $0.347^{* *}$ & 2.02 \\
\hline ln age of ski resort in years & $0.123^{* * *}$ & 4.05 & $0.133^{* * *}$ & 3.23 \\
\hline $\begin{array}{l}\text { dummy variable part of larger ski alliance/ } \\
\text { network }\end{array}$ & 0.038 & 1.55 & 0.023 & 0.60 \\
\hline $\begin{array}{l}\text { share of runs with snowmaking facilities in } \\
\text { per cent }\end{array}$ & $3.596^{* *}$ & 2.33 & 3.391 & 1.08 \\
\hline $\begin{array}{l}\text { share of runs with snowmaking facilities X } \\
\text { ln altitude }\end{array}$ & $-0.473^{* *}$ & -2.36 & -0.447 & -1.09 \\
\hline dummy variable Austria & $-0.045^{* * *}$ & -0.74 & 0.000 & 0.01 \\
\hline dummy variable France & $-0.230^{* * *}$ & -3.61 & $-0.282^{* * *}$ & -2.81 \\
\hline distance to border in $\mathrm{km}$ & 0.000 & 1.24 & 0.000 & 0.48 \\
\hline dummy variable Austria $\mathrm{X}$ distance to border & 0.000 & -0.82 & 0.000 & 0.22 \\
\hline dummy variable France $\mathrm{X}$ distance to border & $-0.001^{* *}$ & -2.33 & $-0.001^{*}$ & -1.85 \\
\hline Constant & -0.725 & -0.90 & -0.491 & -0.34 \\
\hline
\end{tabular}

Notes: Median regressions with bootstrapped standards errors and 1000 replications. Significance at the 1,5 or $10 \%$ level is denoted by ${ }^{* * * * *}$ and ${ }^{*}$, respectively. The estimation sample is restricted to ski areas that are located within the distance of $200 \mathrm{~km}$ or less to the nearest border ski area.

\section{Possible Sources of International Price Differences}

The price differences across countries beg the question of why lift ticket prices (net of VAT) are cheaper in France than in both Austria and Switzerland. Several factors may have an influence on the differences in ski lift ticket prices. Possible explanations include exchange rate movements; differences in cost factors, such as local wages and costs of (non-tradable) intermediate inputs; and firms' mark- 
ups. The latter depends on market structure factors such as the number and concentration of competitors. The first obvious explanation is current exchange rate movements. The CHF/EUR exchange rate has been very volatile since 2008; in particular, the appreciation of the CHF against the EUR in 2009 and 2010 has led to a rise in Swiss ski lift ticket prices when expressed in Euros. However, the price differential between Swiss and French lift tickets still exists, albeit with a smaller magnitude of about 6 per cent when the average nominal exchange rate of CHF1.54/1€ over the period 2000-2009 is used to convert Swiss lift ticket prices into Euros. It is interesting to wonder how much the euro would have to appreciate (against the Swiss franc) to restore uniform prices. The calculations show that the difference in lift ticket prices between France and Switzerland disappears when the exchange rate of CHF1.64/1€ is used to convert lift ticket prices into Euros. However, exchange rates are not relevant in explaining the difference between French and Austrian lift ticket prices.

Non-tradable cost components and wage costs, which can vary across countries, offer another explanation of the price differences. Estimates made by the Swiss Statistical Office show that for total industries, average wage costs per hour are 12 per cent higher in Switzerland than in France and 23 per cent higher than in Austria based on data for 2006. With the recent depreciation of the euro against the Swiss franc (data refers to the period summer 2010), these wage differences might increase to 23 and 40 per cent, respectively. But even when wages are significantly higher in Switzerland than those in Austria and France, this is unlikely to lead to large differences in factor costs. The reason is that lift companies are characterized by high capital intensity with a low share of labour costs in total sales or net output. Although we do not have complete information for all ski areas, calculations based on the reports of the largest ski lift companies in the three countries reveals that the share of wage costs in total output is only about 20 per cent on average. Thus, the relatively high wages in Switzerland translate into production costs that are only 5 per cent higher than in France. When wage costs are measured as labour costs per full-time employee in the sectors transport, storage, and communication, we find that wage costs per employee are higher in France than in Austria ( $€ 38,385$ and $€ 36,610$ for 2007 , respectively $\left.{ }^{5}\right)$. Similarly, based on EUKLEMS data for the same industry, we find that the hourly wage in 2006 was $€ 21.20$ for Austria and $€ 28.10$ for France. This indicates that cost differences are unable to explain the difference between French and Austrian lift ticket prices, but may play a moderate role in the difference between

5 Source: National Accounts by Industry. Eurostat new cronos. 
Swiss and French lift ticket prices. One should also take into account that user costs of capital are lower in Switzerland than in the other two countries because of lower interest rates.

Price differences are caused not only by differences in wage costs, but by differences in non-traded inputs, as well: For ski lift companies, the main non-traded inputs are electricity and water, followed by marketing and insurance expenditures. The prices of these non-tradable inputs are likely to be lower in France and Austria than in Switzerland because the latter country's local wage costs are higher than those of both competitors. Based on reports from the five largest ski lift companies for each country, our calculations suggest that the share of these factors in total output is very small. We thus conclude that differences in the non-traded cost share are unlikely to explain a large part of observed price differences.

Given that cost differences are of minor importance in determining the cause of the price differences, one would expect differences in mark-ups to offer an explanation. In general, mark-ups over marginal costs are inversely related to the price elasticity of demand. Ski lift companies can charge different mark-ups depending on the local demand structure. Monopolists are able to charge high mark-ups when the price elasticity of demand is low (see ENGEL and Rogers, 2004; Krugman, 1987). However, the four-firm concentration ratio is quite low in Switzerland and Austria. In Switzerland, the four largest ski lift companies accounted for 16 per cent of all skier visits in the winter season 2007/2008. ${ }^{6}$ In Austria, the largest ski network (Ski amadé) accounted for 13 per cent of all skier days in the same season. Compagnie des Alpes, however - France's largest ski lift company - accounted for almost 40 per cent of lift ticket sales in the winter season 2008/2009. This rules out market structure as a possible explanation because the country with the lowest lift ticket prices exhibits the largest market concentration.

The price elasticities of domestic and foreign demand are key factors that determine the degree of price discrimination. The large price gap between Switzerland and France may be due to the lower elasticity of demand in Switzerland as compared to France. In general, tourism demand is relatively responsive to price factors (Crouch, 1994; Lim, 2006). Price elasticities may, however, well differ across countries because the structure of international tourists varies by country of

6 The largest ski areas are Davos-Klosters, Zermatt, St. Moritz, and Jungfrau (i.e. Grindelwald, Mürren, and Wengen).

7 The source is Montagne Leaders, October 2009. 
origin. French ski areas have a much lower share of foreign tourists than the two other countries (VANAT, 2011). One tentative explanation is that foreign tourists are less price-sensitive than their domestic counterparts. This may hold in particular for German tourists travelling to Austria (and to the German-speaking part of Switzerland) because these countries are often geographically closer than France and share a similar language. Another factor influencing the relatively high lift ticket prices in Switzerland is the fact that domestic consumers demonstrate a higher marginal willingness to pay because of the much higher GDP per capita and the generally high price level in Switzerland as compared to Austria and France. However, this is only relevant to domestic skiers and is of minor importance for foreign tourists, who represent 50 per cent of the tourists in Switzerland and 75 per cent in Austria (Vanat, 2011).

Productivity and economics of scale are other factors. The more productive a firm is the lower output prices will be given the firm's input prices (FORSYTH and DWYER, 2009). It is also often suggested that ski lift companies are characterized by increasing returns to scale. This means that costs less than double when output doubles, leading to falling average costs. Indeed, FALK (2009) finds some evidence that ski areas representing part of greater ski network - such as Compagnie des Alpes - are significantly more productive. Given that French lift companies are much larger on average, this may explain part of the price differences between Swiss and French lift tickets. Finally, consumer search costs stemming from a lack of information are unlikely to play a role because price differences can be easily checked on the homepages of the ski lift companies.

Overall, we conclude that cost factors are not the main reason behind these price differences. Instead, these differences are most probably demand-driven such that skiers are willing to pay a price premium for Swiss ski resorts.

\section{Conclusion}

Based on a representative data set covering 214 ski resorts in the 2010/2011 season, this study empirically shows that ski lift tickets measured as both oneday and six-day lift tickets (net of VAT) are significantly lower in France than in both Austria and Switzerland. The price differences are 17 per cent between Swiss and French one-day lift ticket prices and 10 per cent between French and Austrian prices after controlling for size, lift capacity (adjusted for vertical transport metres), altitude of uphill lift stations, share of fast lifts, snowmaking facilities, resort age, whether or not each ski lift company belongs to a greater ski network and have been a venue of the FIS Alpine Ski World Cup in the past 15 years. The 
price differential is less pronounced when measured as six-day lift passes with price gap of 14 per cent on average between France and Switzerland and 9 per cent between France and Austria.

Quantile regressions for the $25^{\text {th }}$ and $75^{\text {th }}$ conditional percentile show that the price differential across countries holds for both high-price/high-quality and lowprice/low-quality ski resorts. In addition, the determinants of lift ticket prices are quite similar across the different quantile regressions except for the impact of the share of high-speed lifts, which is less significant for the $75^{\text {th }}$ quantile, i.e. high-price/high-quality ski resorts. Furthermore, we demonstrate that differences in cost factors are not large enough to explain the observed differences in ski lift ticket prices. One obvious factor is the appreciation of the Swiss franc against the euro starting in 2009 starting in 2009 (and continuing into 2011). The price differential between Swiss and French lift ticket prices decreases to 6 per cent when the average CHF/EUR exchange rate of CHF1.54/1€ between the period 2000-2009 is used to convert Swiss lift ticket prices into EUR prices. However, exchange rates are obviously not relevant in explaining the difference between French and Austrian lift ticket prices. Furthermore, we find that the absolute percentage price differences do not increase with the distance to the nearest border ski area.

Given these findings, one might wonder about the implications for policymakers. Consumers are willing to pay a price premium for Swiss ski areas; on the other hand, our results suggest that Swiss ski areas are relatively less pricecompetitive compared to the country's two neighbours given the exchange rate of CHF 1.36/1€ during the 2010 summer period. This would suggest that Swiss ski lift companies need to make further efforts to increase their productivity. It is impossible to determine conclusively which of the two explanations is more relevant. This would require future work, such as an analysis of the subsequent evolution of Swiss ski lift companies' worldwide market share. In particular, it is important to estimate the price elasticity of demand. However, output data is generally only available for large ski lift companies that are legally required to provide annual reports. Governments can also lower their VAT rates. This would be possible in principle for the Swiss authorities, but France and Austria would have limited possibilities to do so because of the European Commission's aim to prevent a growing divergence of VAT rates across EU countries.

Since this study uses data on three Alpine countries, the results should not be over-generalized. In future work, the sample should be extended to other countries - Italy in particular, but also Bulgaria, the Czech Republic, Germany, the Scandinavian countries, Slovakia, Spain, and other countries overseas. Another interesting possible direction for future research is to use discrete choice models to 
estimate the consumers' willingness to pay for different ski destinations. According to the random utility theory consumers choose the alternative that yield the greatest net benefit. In these models utility is a function of ski resorts characteristics and individual characteristics (e.g. age, education, gender, income and location). The advantage of the use of destination choice models is that the willingness to pay can be estimated accurately for different types of consumers. For instance, it would be possible to distinguish between foreign and domestic skiers and snowboarders as well as between day-trippers and those staying in the resort. For the Rocky Mountains and Scotland there are already studies available that investigate the probability of ski resort choice (Moeltner and ENGLin, 2004; Riddington, Sinclair, and Milne, 2000). However, to my knowledge, there are no studies available for the European Alps. Such analysis requires individual data on social economic characteristics and resort data which are rarely available.

\section{References}

Amt der Tiroler Landesregierung (2010), Seilbahnen, Lifte in Tirol, Stand 1.4.2010. Innsbruck.

Bahk, Byong-Hong, and Michael Gort (1993), "Decomposing Learning by Doing in New Plants", Journal of Political Economy, 101, pp. 561-583.

Berwert, Adrian, Franziska Bignasca, and Paolo Filippini (1996), „Preise und Qualitätseigenschaften Schweizerischer Skigebiete: Schätzungen mit dem hedonischen Preisansatz unter Berücksichtigung räumlicher Autokorrelation", Jahrbuch für Regionalwissenschaften 16-17, pp. 67-97.

BMVIT (Federal Ministry for Transport, Innovation and Technology), Eisenbahn-und Seilbahnstatistik der Republik Österreich 2001/2002, Wien.

Borsky, Stefan, and Paul A. Raschky, (2009), "The Hedonics of Hedonism Estimating the Value of Risk-Taking Activities", Kyklos, 62, pp. 210-225.

Broda, Christian M., and David E. Weinstein (2008), Understanding International Price Differences Using Barcode Data, NBER Working Papers 14017, National Bureau of Economic Research.

Brynjolfsson Erik, and Lorin M. Hitt (2003), "Computing Productivity: Firm-Level Evidence", The Review of Economics and Statistics 85, 4, pp. 793-808.

Cabolis Christos, Sofronis Clerides, Ioannis Ioannou, and Daniel Senft (2007), "A Textbook Example of International Price Discrimination", Economics Letters 95 (1), pp.91-95. 
Commission of the European Communities (2002), "Price Differences for Supermarket Goods in Europe", Internal working document DG internal market. Brussels.

Crouch, Geoffrey I. (1994), "The Study of International Tourism Demand: A Review of Findings", Journal of Travel Research, 33 (1), 1994, pp. 12-23

Crucini, Mario J., Chris I. Telmer, and Marios Zachariadis (2005), "Understanding European Real Exchange Rates", American Economic Review, 95, pp. 724-738.

Engel, Charles, and John H. Rogers (1996), "How Wide is the Border?", American Economic Review 86, pp. 1112-1125.

Engel, Charles, and John H. Rogers (2004), "European Product Market Integration after the Euro", Economic Policy, 19 (39), pp.347-384.

Engel Charles, John H. Rogers and Shing-Yi Wang, (2003), Revisiting the Border: an assessment of the law of one price using very disaggregated consumer price data, International Finance Discussion Papers 777, Board of Governors of the Federal Reserve System (U.S.).

Falk, Martin (2008), "A Hedonic Price Model for Ski Lift Tickets", Tourism Management, 29 (6), pp. 1172-1184.

Falk, Martin (2009), "Are Multi-Resort Ski Conglomerates more Efficient?", Managerial and Decision Economics 30, pp. 529-538.

Forsyth, Peter, and Larry M. Dwyer (2009), "Tourism Price Competitiveness", The Travel and Tourism Competitiveness Report 2009.

Gould, William W. (1997), "Interquantile and Simultaneous Quantile Regression”, Stata Technical Bulletin 38, pp. 14-22.

Imbs, Jean, Haroon Mumtaz, Morten O. Ravn, and Hélène Rey (2010), “One TV, One Price?”, Scandinavian Journal of Economics, 112, pp.753-781.

Koenker, Roger, and Kevin F. Hallock (2001), "Quantile Regression", Journal of Economic Perspectives, 15, pp. 143-156.

Krugman, Paul (1987), "Pricing to Market when the Exchange Rate Changes", In S. Arndt, and J. Richardson (eds), Real Financial Linkages among Open Economies, pp. 49-70. MIT Press, Cambridge.

Lancaster, Kelvin J. (1971), Consumer Demand: A New Approach. New York: Columbia University Press

Li, Nicholas, Gita Gopinath, Pierre-Olivier Gourinchas, and ChangTai Hsien (2010), "International Prices, Costs and Markup Differences", American Economic Review (forthcoming).

Lim, Christine (2006), "Tourism Demand Modelling: Issues and Implications", in L. Dwyer and P. Forsyth (eds), International Handbook of Tourism Economics, Cheltenham: Edward Elgar, London. 
Moeltner, Klaus, and Jeffrey Englin (2004), "Choice Behavior Under TimeVariant Quality: State Dependence Versus 'Play-It-by-Ear' in Selecting Ski Resorts", Journal of Business \& Economic Statistics, 22 (2), 214-224.

Mulligan, James G., and Emmanuel Llinares (2003), "Market Segmentation and the Diffusion of Quality Enhancing Innovations: The Case of Downhill Skiing", The Review of Economics and Statistics, 85, pp.493-501.

Müller, Hansruedi, and Jürg Michel (2001), "Quality Requirements for Aerial Cableway and Their Services - The Case of Switzerland", Tourism Review, 56, pp. 12-16.

Parsley, David, and Shang-Jin Wei (2001), "Explaining the Border Effect: The Role of Exchange Rate Variability, Shipping Costs, and Geography", Journal of International Economics, 55(1), pp. 87-105.

Riddington, Geoff, Colin Sinclair , and Nicola Milne (2000), "Modelling Choice and Switching Behavior between Scottish Ski Centres", Applied Economics, 32 (8), pp. 1011-1018.

Rosen, Sherwin (1974), "Hedonic Prices and Implicit Markets: Product Differentiation in Pure Competition", Journal of Political Economy 82, 34-55.

Vanat, Laurent (2011), 2011 International Report on Mountain Tourism: Overview of the Key Industry Figures for Ski Resorts, Genève.

\section{Appendix}

Table 8: List of Ski Areas (Based on Ski Resorts with Data on One-Day Lift Tickets)

\begin{tabular}{lll}
\hline Austria & France & Switzerland \\
\hline Alpbach & Alpe d'Huez Auris en Oisans & Adelboden-Lenk \\
\hline Annaberg-Reidllifte & Avoriaz (Portes du Soleil) & Anzère \\
Axamer Lizum & Ax Les Thermes-Bonascre & Arolla \\
Bad Kleinkirchheim & Barèges-La Mongie & Arosa \\
Bergeralm & Cauterets & Bellwald \\
Berwang & Chamonix & Bivio \\
Brandnertal & Chamrousse & Blatten-Belalp \\
Brunnalm & Châtel (Portes du Soleil) & Braunwald \\
Christlum & Combloux-JAILLET-La & Brigels-Waltensburg \\
Dachstein-West & Giettaz & Bruson
\end{tabular}




\begin{tabular}{|c|c|c|}
\hline Austria & France & Switzerland \\
\hline Damüls-Mellau & $\begin{array}{l}\text { Espace Killy Tignes, } \\
\text { Val d'Isère }\end{array}$ & $\begin{array}{l}\text { Champéry-LesCrosets- } \\
\text { Morgins-Torgon }\end{array}$ \\
\hline Diedamskopf & FLAINE (Grand Massif) & Chandolin-St-Luc \\
\hline Dorfgastein-Grossarl & FLAINE-Les Carroz d Arâches & Crans-Montana \\
\hline Ehrwalder Alm & $\begin{array}{l}\text { Font-Romeu, Bolquère- } \\
\text { Pyrénées } 2000\end{array}$ & Davos (Jakobshorn) \\
\hline Fanningberg & Gourette & Davos (Pischa) \\
\hline Fieberbrunn & ISOLA2000 & Davos (Rinerhorn) \\
\hline Filzmoos (Sportwelt) & $\begin{array}{l}\text { La Clusaz Manigod - } \\
\text { La Croix Fry }\end{array}$ & Davos-Klosters \\
\hline Flachau-Wagrein-St.Johann & La Plagne & Davos-Klosters (Madrisa) \\
\hline Gaissau Hintersee & La Rosière & Davos-Klosters (Parsenn) \\
\hline Galtür & La Toussuire (LES SYBELLES) & Elm Sernftal \\
\hline Gargellen Schafberg & Le Corbier（st. D'Arves) & Engelberg \\
\hline Gastein & Le Grand Bornand & Evolène \\
\hline Gerlitzen-Alpe & Le Grand Domaine & Flims-Laax-Falera \\
\hline Glungezer & Les Angles & Flumserberge \\
\hline Golm & Les Arcs & Grächen \\
\hline Grosseck-Speiereck & Les Contamines-Montjoie & Grimentz \\
\hline Grünau-Kasberg & Les Deux-Alpes & Grindelwald all sections \\
\hline Heiligenblut & $\begin{array}{l}\text { Les Gets-Morzine (Portes du } \\
\text { Soleil) }\end{array}$ & $\begin{array}{l}\text { Grindelwald-Mannlichen, } \\
\text { Kleine-Scheidegg - Wengen }\end{array}$ \\
\hline Hinterstoder & Les Houches & Grindelwald-Mürren \\
\hline Hintertuxer Gletscher & Les Menuires & gstaad-Saanenmöser \\
\hline Hochficht & Les Orres & Hoch-Ybrig \\
\hline Hochjoch & Les Saisies & Klewenalp \\
\hline Hochkar & Les Sept Laux & $\begin{array}{l}\text { LenzerheideRothorn- } \\
\text { Schwarzhorn }\end{array}$ \\
\hline Hochkönig & $\begin{array}{l}\text { Megève Combloux- } \\
\text { JAILLET-La Giettaz }\end{array}$ & Leysin \\
\hline Hochötz & Méribel-Mottaret & Meiringen - Hasliberg \\
\hline Hochzeiger & $\begin{array}{l}\text { Montgenevre } \\
\text { Cesana - Clavière }\end{array}$ & Melchsee-Frutt \\
\hline $\begin{array}{l}\text { Hochzillertal-Hochfügen- } \\
\text { Kaltenbach }\end{array}$ & Monts Jura Mijoux & Morgins \\
\hline
\end{tabular}




\begin{tabular}{|c|c|c|}
\hline Austria & France & Switzerland \\
\hline Innerkrems & Orcieres 1850 Merlette & Nax - Mont-Noble \\
\hline Ischgl-Samnaun & Paradeski Les Arcs La Plagne & Nendaz-Veysonnaz-Thyon \\
\hline Kals-Matrei & Peyragudes & Obersaxen \\
\hline Kappl & Praz de Lys Sommand & Ovronnaz \\
\hline Katschberg & Puy Saint Vincent & Pizol \\
\hline Kaunertaler Gletscher & $\begin{array}{l}\text { Risoul } 1850 \text { (Domaine de la } \\
\text { Forêt Blanc) }\end{array}$ & Riederalp \\
\hline Kitzbühel & Saint Lary Soulan & Rosswald \\
\hline Kitzsteinhorn & Serre-Chevalier & Saas Fee \\
\hline Kössen & $\begin{array}{l}\text { St. Francois longchamp (Le } \\
\text { Grand Domaine) }\end{array}$ & San Bernardino \\
\hline Kreischberg & St. Sorlin d'Arves & Savognin \\
\hline Kühtai & Super besse (Le Mont-Dore) & Scuol-Ftan \\
\hline Lech-Zürs (Ski Arlberg) & Superdevoluy La joue du Loup & Sedrun-Disentis \\
\hline Lermoos-Biberwier & TIGNES (espace killy) & Sörenberg \\
\hline Lofer & trois vallée & Splügen \\
\hline Loser-Sandling & Val Cenis & $\begin{array}{l}\text { St. Moritz Corvatsch- } \\
\text { Silvaplana }\end{array}$ \\
\hline Mayrhofen (Zillertal 3000) & Val d Isère (Espace Killy) & St. Moritz-Zuoz \\
\hline Mölltaler Gletscher & Val D'Allos - Le Seignus & St. Moritz \\
\hline Naßfeld-Hermagor & Val Thorens & St. Moritz-Diavolezza \\
\hline Nauders & $\begin{array}{l}\text { Vallée des Belleville, } \\
\text { Val-Thorens, Orelle, } \\
\text { Les Ménuires, Saint-Martin } \\
\text { de Belleville }\end{array}$ & St. Moritz-Celerina \\
\hline Obergurgl-Hochgurgl & Valloire-Valmeinier & Stoos \\
\hline Obertauern & Villard de Lans & Val Müstair \\
\hline Patscherkofel & & Verbier \\
\hline Pitztaler Gletscher & & Vercorin \\
\hline $\begin{array}{l}\text { Planai-Hochwurzen-Hauser } \\
\text { Kaibling-Reiteralm }\end{array}$ & & Villars-Gryon \\
\hline $\begin{array}{l}\text { Radstadt/Altenmark } \\
\quad \text { (Sportwelt) }\end{array}$ & & Wildhaus \\
\hline Rauris & & Wiler-Lauchernalp \\
\hline
\end{tabular}




\begin{tabular}{|c|c|c|}
\hline Austria & France & Switzerland \\
\hline Riesneralm & & Zermatt \\
\hline $\begin{array}{l}\text { Saalbach-Hinterglemm- } \\
\text { Leogang (Skicirkus) }\end{array}$ & & Zinal (Val d'Anniviers) \\
\hline \multicolumn{3}{|l|}{ Schmittenhöhe } \\
\hline \multicolumn{3}{|l|}{ See } \\
\hline \multicolumn{3}{|l|}{ Seefeld-Rosshütte } \\
\hline \multicolumn{3}{|l|}{ Semmering (Hirschenkogel) } \\
\hline \multicolumn{3}{|l|}{ Serfaus-Fiss-Ladis } \\
\hline \multicolumn{3}{|l|}{ Sillian (Hochpustertal) } \\
\hline \multicolumn{3}{|l|}{ Silvretta Nova } \\
\hline \multicolumn{3}{|l|}{ Skiwelt } \\
\hline \multicolumn{3}{|l|}{ Sölden } \\
\hline \multicolumn{3}{|l|}{ Sonnenkopf } \\
\hline \multicolumn{3}{|l|}{ Spieljoch-Fügen } \\
\hline \multicolumn{3}{|l|}{ Sportgastein } \\
\hline \multicolumn{3}{|l|}{ St. Anton } \\
\hline \multicolumn{3}{|l|}{ Steinplatte } \\
\hline \multicolumn{3}{|l|}{ Stubaier Gletscher } \\
\hline \multicolumn{3}{|l|}{ Stuhleck (Semmering) } \\
\hline \multicolumn{3}{|l|}{ Tauplitz } \\
\hline \multicolumn{3}{|l|}{ Turracher Höhe } \\
\hline \multicolumn{3}{|l|}{ Venet } \\
\hline \multicolumn{3}{|l|}{ Warth-Schröcken } \\
\hline \multicolumn{3}{|l|}{ Werfenweng } \\
\hline \multicolumn{3}{|l|}{ Wildkogel } \\
\hline \multicolumn{3}{|l|}{ Wildschönau-Auffach } \\
\hline \multicolumn{3}{|l|}{$\begin{array}{l}\text { Zauchensee-Flachauwinkl- } \\
\text { Kleinarl }\end{array}$} \\
\hline \multicolumn{3}{|l|}{ Zettersfeld } \\
\hline Zillertal Arena & & \\
\hline
\end{tabular}




\section{SUMMARY}

This paper provides empirical evidence on international price differences in ski lift tickets based on 214 ski areas in Austria, France, and Switzerland for the winter season 2010/2011. We find that French and Austrian one-day lift tickets (net of VAT) are an average of 17 and 7 per cent lower, respectively, than Swiss ticket prices after controlling for ski areas' characteristics. The results of quantile regressions show that the magnitude of the international price differences is quite similar for low- and high-priced ski areas. Furthermore, price differences across countries do not increase with distance to the nearest border ski area. 